2. Бойко Н.В., Бачурина А.С. Аденотомия и аденотонзиллотомия у детей с затруднением носового дыхания. Рос. ринология 2015; 23 (1): 9-12.

3. Бойко Н.В., Бачурина А.С., Оксенюк О.С., Колмакова Т.С. Лечение послеоперационного воспаления после тонзиллэктомии у детей. Педиатрия, 2016, т. 95, № 1. С. 93-97.

4. Gates G.A., Folbre T.W. Indications for adenotonsillectomy //Arch. Otolaryngol. Head Neck Surg. 1986; 112: 501-502.

5. Parker, D.L. Walner N.P. Trends in the indications for pediatric tonsillectomy or adenotonsillectomy // International Journal of Pediatric Otorhinolaryngology 2011; 75: 282-285.

6. Owings M.F., Kozak L.J. Ambulatory and in patient procedure sin the UnitedStates, National Center for Health Statistics. (1996) Available at: http://www.cdc.gov/ nchs/data/series/sr_13/sr13_139.pdf (accessed October 10, 2010).

7. Бойко Н.В., Локшина Л.С., Сорока Г.Г., Бриж Ю.В., Сулина Н.Ю. Изменение подходов к лечению хронического тонзиллита в детском возрасте по материалам Ростовской ЛОР клиники. Вестник оторинолар. 2012; 5: 226.

8. Власова Т.М., Бойко Н.В. Рост числа постстрептококковых осложнений у больных хроническим тонзиллитом. Рос. оторинолар. 2015; S1: 45-47.

9. Белов Б.С. Острая ревматическая лихорадка и инфекционно-воспалительные заболевания глотки: сопряженность, лечение, профилактика. Вестник оторинолар. 2015; 80 (2): 4-7.

10. Galioto N.J. Peritonsillar abscess //American Family Physician 2008; 77 (2): 199-203.

\title{
Киселева Е.В. \\ Влияние занятий физическими упражнениями на развитие детей, имеющих тетропарез верхних (нижних) конечностей
}

ГБПОУ Самарской области «Самарский социально-педагогический колледж» (Россия, Самара)

doi:10.18411/lj2016-4-27

В последние годы акцент в отношении детей-инвалидов сместился с проблем выживания на качество жизни. Важным фактором, лимитирующим качество жизни детей-инвалидов с тетрапарезом, служит ограничение двигательной активности. По мнению О.Э. Аксеновой, С.И. Веневцева, А.А. Дмитриева и др.О.Э. Аксенова, С.И. Веневцев, А.А. Дмитриев, В.П. Жиленкова, С.Ф. Курдыбайло, Н. Л. Литош, Е.М. Мастюкова, С.П. Евсеев, Л.Н. Ростомашвили, Л.В. Шапкова и др., дети-инвалиды с тетрапарезом в первую очередь нуждаются в восстановлении функции сидения и работы верхних конечностей. Это открывает им возможности самообслуживания, перемещения в кресле-коляске.

Среди методов восстановления двигательной активности основное внимание отводится лечебной и адаптивной физической культуре. Возможности выполнять активные упражнения, у детей-инвалидов с тетрапарезом ограничены, поэтому при организации занятий физкультурой особое внимание уделяют рефлекторным упражнениям, движениям в условиях замкнутой биокинематической цепи.

С.П. Евсеев и Л.Н. Ростомашвили напоминают, чтоиспользование физических упражнений позволяет организовать движения всех частей тела человека в условиях замкнутойбиокинематической цепи, активизировать вестибулотонические, симметричные и асимметричные шейнотонические рефлексы, проприоцепторы поясничного отдела, рук, плечевого отдела, включить в работу максимальное количество мышечных групп. В зависимости от состояния здоровья и тренированности использование физических упражнений позволяет осуществлять частичную разгрузку или дозированную нагрузку определенных звеньев двигательного аппарата.Однако пациенты с тетрапарезом не могут самостоятельно выполнять упражнения. Они нуждаются в помощи других людей.

Мы попытались опробовать на практике эффективность использования физических упражнений при тетрапарезе на двигательную активность детей среднего дошкольного возрастаГБУСамарской области «Сергиевского пансионата для детей инвалидов (12 детей пятого года жизни).

Исследование проводилось с ноября 2015 года - по март 2016 года.

Поставили цель - изучить возможность использования комплекса физических упражнений для формирования двигательных функций у детей среднего дошкольного возраста с тетрапарезом. 
Гипотеза исследования - занятия физическими упражнениями могут позволить активизировать двигательные навыки детей 5-6 лет с заболеванием тетрапарезом и способствовать восстановление функции сидения и работы верхних конечностей.

Были проведены три этапа эксперимента: констатирующий, формирующий и контрольный. На формирующем этапе проводился курс ЛФК.

Обследование перед началом и после окончания курса ЛФК включало: осмотр, измерение объема движений в суставах верхних конечностей, силы мышц верхних конечностей и плечевого пояса.В качестве контрольно-измерительных тестов были выбраны: отбивание мяча от пола, передача мяча от груди, подбрасывание и ловля мяча.

Т.к. дети не имели противопоказаний к занятиям физической культурой,на формирующем этапе выбирались комплексы простых однотипных упражнений, охватывающих различные мышечные группы (отвечающих принципу рассеянности нагрузки). Основные физические усилия при этом приходились на здоровые мышцы, денервированные мышцы включались в работу пассивно (самим больным) или с помощью инструктора.

Методика подбора и проведения упражнений строилась на рекомендацияхН.А. Гросс [1], А.И. Журавлевой [3]. Включались специальные упражнения на фитболе курс 10 процедур. Занятия проводились ежедневно, с помощью ассистентов под руководством методиста дома интерната для детей инвалидов с детьми выполняли упражнения из исходных положений:лежа на животе на фитболе, лежа на спине на фитболе, сидя на фитболе.

Упражнения, тренирующие одни и те же функции из одного исходного положения, были объединены в серию, где наиболее простые упражнения проведены в начале, сложные - в конце. По мере расширения двигательные навыков переходили от простых упражнений к более сложным. Каждое упражнение повторялось 2-4 раза.

Структура занятий была общепринятой: подготовительная, основная и заключительная части. На базовую составляющую уделялось не менее $40 \%$ времени, отводимого на все занятие. При этом она выполняла роль углубленной подготовительной части с более широким спектром использованных средств, чем в традиционных занятиях.Результаты констатирующего и контрольного этаповв динамике представлены в таблице 1.

Таблий 1.

Результаты констатирующего и контрольного этапов в динамике.

\begin{tabular}{|c|c|c|c|c|c|c|c|}
\hline \multirow[t]{3}{*}{ № } & \multirow{3}{*}{ Фамилия, имя } & \multicolumn{6}{|c|}{ Тесты } \\
\hline & & \multicolumn{2}{|c|}{$\begin{array}{c}\text { Подбрасывание и } \\
\text { ловля мяча, к-во раз }\end{array}$} & \multicolumn{2}{|c|}{$\begin{array}{l}\text { Передача мяча от } \\
\text { груди, к-во раз }\end{array}$} & \multicolumn{2}{|c|}{$\begin{array}{c}\text { Отбивание мяча от } \\
\text { пола, к-во раз }\end{array}$} \\
\hline & & Конст. & Кконтрол. & Конст. & Контрол. & Конст. & Контрол \\
\hline 1. & Мальков А. & 5 & +2 & 8 & +6 & 5 & +5 \\
\hline 2. & Петров А. & 7 & +1 & 8 & +8 & 5 & +3 \\
\hline 3. & Марчук А. & 6 & +1 & 6 & +9 & 5 & +7 \\
\hline 4. & Кусанов А. & 5 & +2 & 8 & +5 & 5 & +1 \\
\hline 5. & Кузнецов М & 4 & +3 & 7 & +3 & 4 & +4 \\
\hline 6. & Рубинков А. & 4 & +3 & 8 & +7 & 5 & +5 \\
\hline 7. & Обгольц Е. & 5 & +0 & 6 & +1 & 6 & +8 \\
\hline 8. & Старценко Д & 5 & +1 & 8 & +4 & 6 & +6 \\
\hline 9. & МельниковМ & 7 & +2 & 7 & +5 & 5 & +2 \\
\hline 10 & Закодырин А. & 4 & +1 & 8 & +8 & 5 & +5 \\
\hline 11 & Запорожец C. & 4 & +1 & 7 & +6 & 6 & +3 \\
\hline 12 & Сорокин Д. & 5 & +2 & 8 & +2 & 5 & +7 \\
\hline \multirow{2}{*}{\multicolumn{2}{|c|}{$\sum$}} & \multirow[t]{2}{*}{61} & +19 & \multirow[t]{2}{*}{89} & +64 & \multirow[t]{2}{*}{62} & +56 \\
\hline & & & 80 & & 153 & & 118 \\
\hline & $\mathrm{x}_{\mathrm{i}}$ & 5,08 & 6,66 & 7,41 & 12,75 & 5,16 & 9,83 \\
\hline
\end{tabular}


Результаты теста на контрольном этапе исследования, показали положительную динамику в развитии двигательной системы детей. Выявленная динамика по всем замерам представлена на рис 1.

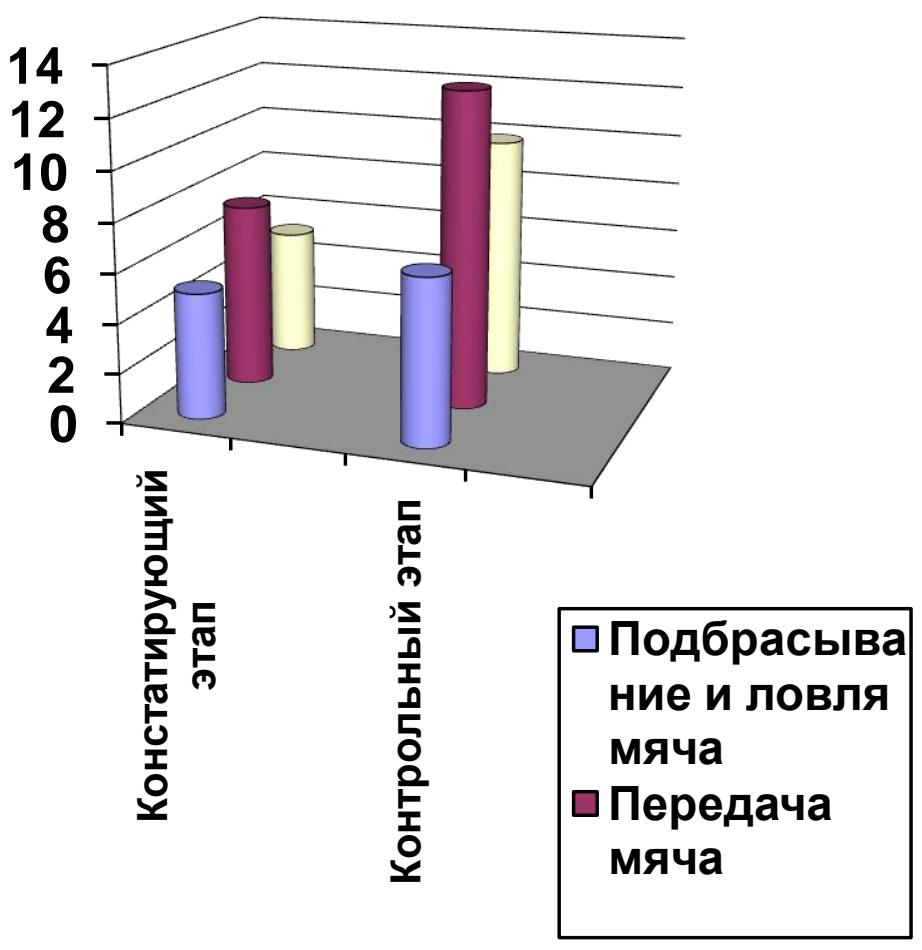

Рис. 1. Физические показатели на контрольном этапе исследования.

В итоге у детей среднего дошкольного возраста с тетрапарезом - уровнем повреждения позвоночника и спинного мозга в результате курса тренировок восстановился объем разгибания в суставах кисти и пальцев. Наблюдалось увеличение объема разгибания в плечевых, локтевых, суставах.

Четыре ребёнка научились полностью разгибать руки в локтевых суставах и самостоятельно удерживать руки в упоре на полу, лежа на фитболе, 3 человека научились самостоятельно выполнять шаг рукой в положении лежа на фитболе. Все пациенты стали более уверенно опираться на верхние конечности, научились напрягать мышцы плечевого и тазового пояса, спины, живота.

У всех детей среднего дошкольного возраста с тетрапарезом в разной степени улучшилась функция сидения: 1 - научился сидеть без посторонней помощи, дополнительной опоры спиной или руками; 5 - функция улучшилась в пределах первого уровня компенсации: пациенты научились удерживать позу сидя с опорой руками о бедра или о подлокотник кресла-коляски, научились выпрямлять спину и удерживать ее прямой в положении сидя в течение нескольких минут.

Двое: исходно умели сидеть неподвижно без дополнительной опоры туловищем или руками, а после тренировок - освоили движения головой руками, корпусом в положении сидя без дополнительной поры.

Позитивным результатом можно считать и то, что за период формирующего этапа все дети среднего дошкольного возраста с тетрапарезом научились выполнять упражнения без помощи методиста, понимать логику построения занятия. Все занимавшиеся выразили готовность продолжить занятия дома.

Таким образом, применённая в иследовании методика развития двигательных качеств верхних конечностей, основанная на комплексном использовании средств физических упражнений и фитбола по рекомендациям Н.А.Гросс, А.И. Журвлёвой и др. может быть рекомендована для развития движений детей с тетропарезомверхних (нижних) конечностей.

Методика включает три этапа: подготовительный, развивающий, соревновательный. Основными задачами этапов, являются развитие физических качеств в стандартных, усложненных условиях при групповом взаимодействии детей и 
в соревновательных условиях. В процессе двигательной деятельности детей необходимо использовать средства психолого-педагогического воздействия (установки, внушения, педагогическая оценка, эмоциональный комментарий) и коммуникативные игры.

\section{Список используемых источников информации}

1. Гросс, Н.А. Физическая реабилитация детей с нарушениями функций опорно-двигательного аппарата: учебное пособие /под ред.Н.А. Гросс,- М.: Советский спорт, 2000. 224c.

2. Лечебная физкультура в системе реабилитационных мероприятий с позиций доказательной медицины // «Российская ассоциация по спортивной медицине и реабилитации больных и инвалидов» / Журавлева, А.И. № 1. 2004. с. 16-19.

3. Потапчук А.А. Осанка и физическое развитие детей (программа диагностики и коррекции нарушений): уч. пособие /под ред. А.А.Потапчук- СПб.: Речь, 2001.-166с.

\section{Манжуева Н. Ф. \\ Государственная политика в области музыкального образования Республики Саха (Якутия)}

ГБУ РС (Я) «Образовательный ресурсный иеентр» (Россия, Якутск) doi:10.18411/1j2016-4-28

Музыкальное искусство во всем его многообразии является неотъемлемой и весьма существенной частью культуры. В свою очередь, система музыкального образования, призванная вести подготовку профессиональных музыкантов, выполняет роль фундамента музыкального искусства.

В Республики Саха (Якутия) создана и работает трехступенчатая система предпрофессионального и профессионального музыкального образования. Детских музыкальных школ и детских школ искусств, где есть музыкальные отделения,- 80, в них обучаются 4777 учащихся. Среднее профессиональное образование представлено в республике старейшим учреждением - Якутским музыкальным колледжем им М.Н.Жиркова. Это ведущее образовательное учреждение по подготовке профессиональных музыкантов и педагогических кадров для детских музыкальных школ и школ искусств Республики Саха (Якутия). 30 декабря 1992 г. Указом Президента Республики Саха (Якутия) М. Е.Николаева «О Государственной поддержке в сфере культуры и искусства в РС (Я)» открыта Республиканская школа музыки для особо одаренных детей . Главной задачей Высшей школы музыки является подготовка высокопрофессиональных кадров для республики. За годы деятельности ВШМ было создано множество учебных творческих коллективов - симфонический оркестр в составе 50 человек, камерный и духовой оркестры, ансамбль скрипачей, квартет виолончелистов, квинтет деревянных духовых инструментов, брасс-квинтет. Кроме данных образовательных учреждений функционирует Федеральный Арктический государственный институт искусств и культуры, где есть факультет исполнительских искусств, состоящий из кафедр вокального искусства и инструментального исполнительства.

По новому закону «Об образовании» правовой статус детских школ искусств определяется как осуществление предпрофессионального образования в сфере культуры и искусств. За последние годы в системе ДМШ возникли множество системных проблем из-за отсутствия единых требований к образовательному процессу. Нормативно-правовые документы последних лет вызывают осторожный оптимизм и веру, что детские музыкальные школы вернут утраченные позиции. Введение Федеральных государственных требований к содержанию, структуре, условиям реализации и срокам обучения по предпрофессиональным программам поможет им выйти на новый уровень развития. Процесс, через который предстоит пройти музыкальным школам, труден, так как требует перестройки мировоззрения многих руководителей и преподавателей. Министерство культуры и духовного развития Республики Саха (Якутия) в сотрудничестве с муниципальными образованиями, республиканскими органами исполнительной и законодательной власти проводит целенаправленную политику в целях успешного функционирования детских музыкальных школ. Организуются видеоконференции с руководителями 